\title{
トカマクにおける中性子発生率測定
}

\author{
西 谷 健 夫 \\ (日本原子力研究所那珂研究所)
}

(1992年 4 月15日受理)

\section{Neutron Yield Measurement in Tokamaks}

Takeo Nishitani

(Received April 15, 1992)

\begin{abstract}
Absolutely calibrated measurements of the neutron yield are important for the evaluation of the plasma performance such as the fusion gain $Q$ in D-D operating tokamaks. Time-resolved neutron yield is measured with neutron detectors using fission chamber in large tokamaks. The neutron detectors are calibrated by moving the ${ }^{252} \mathrm{Cf}$ neutron source toroidally through the vacuum vessel. In JT-60U, the detection efficiencies were measured by the toroidal scan of the neutron point source resulting the uncertainty of $\pm 11 \%$. The maximum neutron yield of $1.3 \times 10^{16} \mathrm{n} / \mathrm{s}$ and the fusion gain $Q_{\mathrm{DT}}$ of 0.2 were obtained in the initial D-D experiment of JT-60U.
\end{abstract}

Keywords :

neutron yield measurement, tokamak, absolute neutron calibration, fisson chamber, fusion reactivity, fusion gain,

\section{1. はじめに}

重水素放電を行うトカマクにおける中性子計測は, 当初は中性子エネルギースペクトルのドップラー効果 を利用したイオン温度測定法とみなされていたが ${ }^{1)}$, この方法は $\mathrm{OH}$ 放電のみで有効であり, 現在のトカ マク実験の主な興味の対象である中性粒子入射(NBI) 加熱プラズマなどの追加熱プラズマでは, 次章の述 ベるようにビームなどの高速イオンによって発生する中性子が主になるため, 中性子スペクトルからイオン 温度を求めることは困難である。また中性子スペクトロメータのダイナミックレンジの制限からどの放電で もイオン温度を出すという訳にはいかず，適切な中性子発生率の放電において 0.5 1s 毎にイオン温度を 得たのが現在までの最良の例であり, 定常的なイオン温度測定手段とはなり得ていないのが現状である.

Naka Fusion Research Establishment, Japan Atomic Energy Research Institute, Ibaraki 319-11. 
一方, JET, JT-60U, TFTR ど, プラズマの性能がブレークイーブン(核融合利得 $Q=1$ ) 条件に近づい てくると, 核融合出力, 重水素プラズマの核融合利得 $Q_{\mathrm{DD}}$ または, それから換算した DT プラズマの 核融合利得 $Q_{\mathrm{DT}}$ の議論が重要になり, それを測定する手段として, 中性子発生率の絶対測定が重要になっ てきている，またこれまでプラズマ性能のパラメータとして蓄積エネルギーが用いられてきたが，中性子発 生率は蓄積エネルギーとは異なったプラズマパラメー夕依存性を有している。例えば, 中性子発生率は不純 物による燃料希釈のために実効電荷数 $Z_{\mathrm{eff}}$ や $\mathrm{H} / \mathrm{D}$ 比に敏感であるのに対し, 蓄積エネルギーはそれらに それほど敏感でない，また中性子発生率ではNBI な゙による高速イオンの存在がより強調されて現れる等 の違いがある。したがって, トカマクプラズマの輸送解析を行う上で, 蓄積エネルギーと同様に中性子発生 率も巨視的パラメータとなってきている2).

本稿では, トカマクで行われている中性子発生率測定の現状と, 中性子発生率測定で最も大きな課題であ る，その絶対較正について述べ，最後にJT-60Uに拈ける最近の測定結果を紹介する.

\section{2. 中性子の発生過程}

はじめに磁場閉じ込めプラズマ, 特にNBI 加熱プラズマに扔ける中性子発生過程を簡単に復習してお く，NBI でなくともイオンの速度分布関数にテイルを有するような加熱方法であれば，議論は同じである. NBI 加熱プラズマにおいて中性子は, 熱核融合反応(熱成分一熱成分), ビーム成分一熱成分反応，ビーム成 分一ビーム成分反応の 3 つの過程で発生する，中性子発生率を $S_{\mathrm{n}}$ とすると，

$$
S_{\mathrm{n}}=n_{\mathrm{D}}^{2} V K_{1}\left(T_{\mathrm{i}}\right)+\left\langle\frac{n_{\mathrm{D}}}{n_{\mathrm{e}}}\right\rangle P T_{\mathrm{e}}^{3 / 2} K_{2}\left(E_{0}, T_{\mathrm{e}}, T_{\mathrm{i}}\right)+\frac{P^{2} T_{\mathrm{e}}^{3}}{\left\langle n_{\mathrm{e}}^{2}>V\right.} K_{3}\left(E_{0}, T_{\mathrm{e}}\right)
$$

で表される ${ }^{3)}$. 右辺の各項はそれぞれ熱核融合反応，ビーム成分一熱成分反応，ビーム成分一ビーム成分反 応に対応している。ここで，Pは入力パワー，Vはプラズマ体積， $K_{i}$ はそれぞれの過程の反応に寄与する イオンの速度空間で平均した核融合反応率 $<\sigma v>$ $\sigma る$. 第 2 項および 3 項の $T_{\mathrm{e}}{ }^{3 / 2}, T_{\mathrm{e}}{ }^{3}$ は高速イオン の減速時間の電子温度依存性として現れる。重水素プラズマでは, 核融合反応率 $K_{1}$ はイオン温度の強い関 数であり, $T_{\mathrm{i}} \sim 3 \mathrm{keV}$ では $T_{\mathrm{i}} \sim 4$ 程度の依存性を持つ. 一方, $K_{2}, K_{3}$ は重水素ビーム入射の場合イオン 温度に対し弱い増加関数である. $K_{1}, K_{2}, K_{3}$ の具体的な形や数值は文献 ${ }^{4 \sim 7)}$ を参照されたい.

\section{3. 中性発生率計測}

トカマクにおける中性子発生量の計測は放射化箔法と中性子検出器(中性子カウンター)で行われている. 放射化䈃法は金属䈃を放電前に気送管で真空容器近傍に送り込み，放電後回収してその放射化量から中性子 発生量を求めるもので, $\mathrm{JET}^{8)}, \mathrm{TFTR}^{9)}$ 等で行われている。測定量は放電中の積算値であるので, 時間変 化が解らないという欠点はあるが, $\gamma$ 線やその他のノイズに全く不感であり，本質的にその位置における中 
性子束に対しては絶対測定である。しかし実験上は,やはり中性子発生率の時間変化に興味が持たれる。そ こで，本稿では中性子検出器による中性子発生率の時間変化測定を中心に述べる．

\section{1 中性子検出器の選択}

現在の大型トカマク装置の NBI 加熱実験では高速イオンの減速時間程度 ( 100ms)のタイムスケール で中性子発生率が $10^{4} \sim 10^{6}$ 変化するので, 中性子検出器には広いダイナミックレンジと速い時間応答性が要 求される。また $\gamma$ 線や硬X線を容易に弁別できることも必要である。このような広いダイナミックレンジと 速い時間応答性を 1 つの中性子検出器で満たすためには, パルスを一つ一つ計測するいわゆるパルス計数 モードのみでは不可能であり， DC 的に測定できること(電流モードなど)が必要である，

中性子検出器としては, $\mathrm{BF}_{3}$ 比例計数管, ${ }^{3} \mathrm{He}$ 比例計数管, フィッションチェンバーなどがあるが, $\mathrm{JT}^{-60 \mathrm{U}^{10)}}, \mathrm{JET}^{11)}, \mathrm{TFTR}^{12,13)}$ など大型トカマク装置では, フィッションチェンバーが主流となって いる. $\mathrm{BF}_{3}$ 比例計数管や ${ }^{3} \mathrm{He}$ 比例計数管は ${ }^{10} \mathrm{~B}(\mathrm{n}, \alpha){ }^{7} \mathrm{Li}$ と ${ }^{3} \mathrm{He}(\mathrm{n}, \mathrm{p}) \mathrm{T}$ 反応を利用しており, 反応の発生

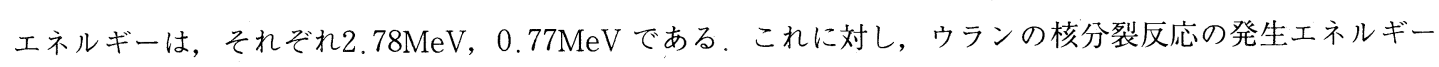
は $200 \mathrm{MeV}$ 近く, バックグラウンドとなる, 硬 $\mathrm{X}$ 線や $\gamma$ 線(約 $10 \mathrm{MeV}$ 以下)を容易に弁別することができ る. また比例計数管では, 高計数率になってくると電子に比べて移動度の小さい陽イオンが管内に残り, 実 効的な電界が低下し(空間電荷効果), ガス増幅率が減少する。したがってパルスを一つ一つ計数できないよ うな高計数率領域で電流モードによって測定しょうとしても, 出力電流と計数率の直線性は失われてしま う。それ対し電離箱では, ガス増幅を行わないので陽イオンによる空間電荷効果は起こりにくく, また起 こって多少の電界が変動してもパルス波高(または検出中性子 1 個当たりの出力電流)に変化を生じないので 電流モードで使用すれば, 広い中性子束に対し, 直線性が得られる。

フィッションチェンバーは電離箱領域で作動しているので, 電流モードでの測定が可能であり, また核分 裂によって放出されるエネルギーが大きいので一つ一つのパルスの電荷量が大きく，ガス増幅なしでもパル ス計数モードでの使用も可能である。したがって, フィッションチェンバーはトカマクの中性子発生率測定 に最も適した中性子検出器であるといえる。

\section{2 フィッションチェンバーを用いた中性子検出器}

大型トカマクでは ${ }^{235} \mathrm{U}$ と ${ }^{238} \mathrm{U}$ のフィッションチェンバーを用いた中性子検出器を一対で使用している. 図! にJT-60Uに使用されているフィッションチェンバーの中性子検出器の構造を示す ${ }^{10)}$. よく知られて いるように ${ }^{235} \mathrm{U}$ の核分裂反応断面積は $1 / v(v$ ：中性子の速度) 依存性をもっているので, 核融合反応からの 中性子に対する検出感度を大きくするために, ポリエチレンの減速材で, フィッションチェンバーを囲んで おり, さらに, 実験室内で熱化した中性子の寄与を除くために，カドミュウムで外側を被っている，ポリエ チレンの減速材の厚さを変えたときの検出感度曲線( 1 次元中性子輸送コード ANISNによる)を図 2 示す. 

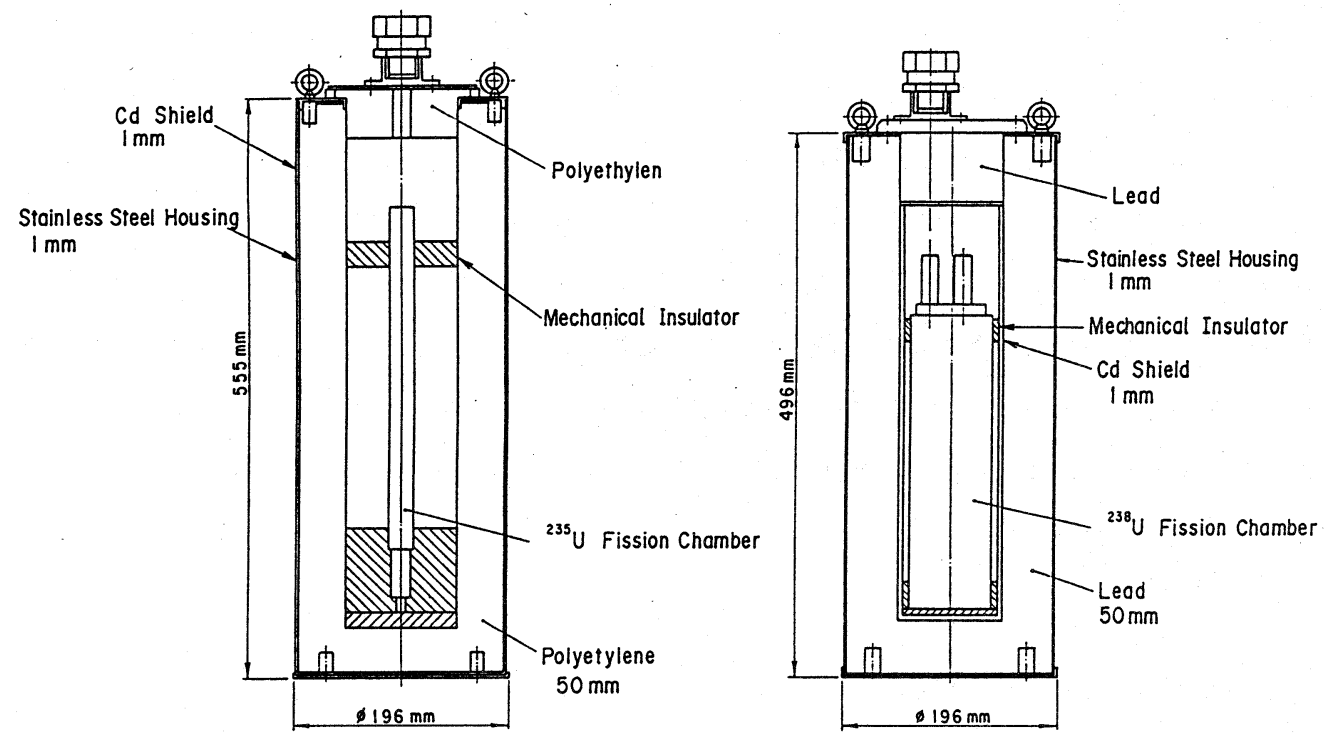

図 1.JT-60U におけるフィッションチェンバーを用いた中性子検出器の構造.

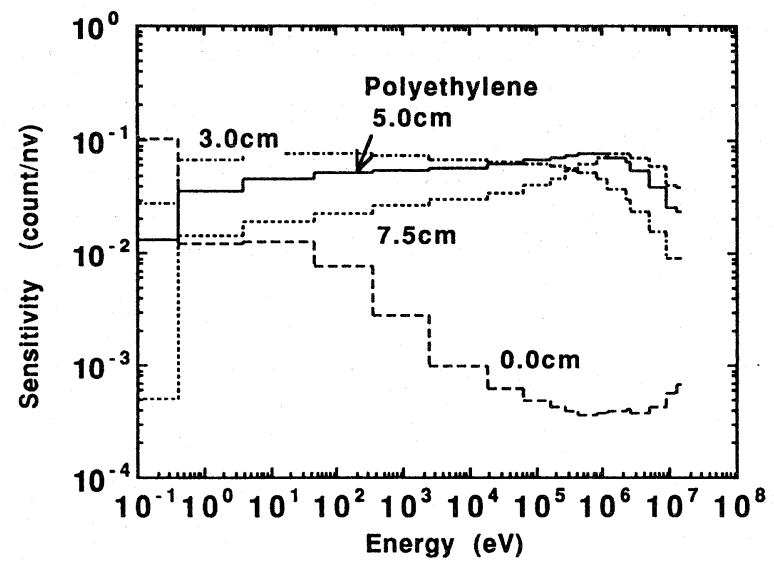

図 2. ${ }^{235}$ フィッションチェンバーを用いた中性子検出器の感度曲線の 減速材厚依存性 ( 1 次元中性子輸送コードANISN による).

これからポリエチレンの減速材厚を $5 \mathrm{~cm}$ にすれば $\mathrm{MeV}$ 領域から $\mathrm{eV}$ 領域に渡ってほぼ一定の検出感度が 得られることがわかる。

同じウランの量を使用した場合, ${ }^{238} \mathrm{U}$ のフィッションチェンバーを用いた中性子検出器の感度は ${ }^{235} \mathrm{U}$ の中性子検出器の約 $10^{-3}$ である。現在の重水素放電では ${ }^{235} \mathrm{U}$ の中性子検出器のみで十分測定可能である が, DT 放電の計画 (JET, TFTR) $500 \mathrm{keV}$ 負イオン源 NBI の計画 (JT-60U) があり，その際の高い中性子 発生率に対応するため, ${ }^{238} \mathrm{U}$ の中性子検出器も用意している。 ${ }^{238} \mathrm{U}$ の核分裂反応は約 $1 \mathrm{MeV}$ 以上の中性子 に対して起こるので, ${ }^{238} U$ の中性子検出器の感度曲線は ${ }^{235} U$ のものと大きく異なる。したがって単に感度 
が小さい検出器が必要なだけならば ${ }^{238} \mathrm{U}$ を用いるより, ウランの量が少ない ${ }^{235} \mathrm{U}$ の検出器を用いる方が 好ましいが，その感度曲線の違いを利用して DD 反応に付随して発生する $14 \mathrm{MeV}$ 中性子の量などの情報を 得ることができる ${ }^{14)}$ 。 ${ }^{238} U$ の場合は, 中性子検出感度が ${ }^{235} U$ より小さいので， $\gamma$ 線の影響が，それだけ 相対的に大きくなる，そのために，厚い $\gamma$ 線遮蔽 $(\mathrm{JT}-60 \mathrm{U}$ では鉛 $5 \mathrm{~cm}$ 厚) を必要としている.

パルス計数モードでは波高の違いによって $\gamma$ 線の影響を容易に除去することができるが，電流モードで は，波高が小さくてもその量が多くなれば電流としては無視できなくなる，そこでJT-60Uでは，電流モー ドの一種であるキャンベルモード(MSV モード)を採用している，キャンベルモードは次のようなキャンベ ルの定理に基づき，出力電流の変動の 2 乗平均(分散)からパルス計数率を求めるものである.

$$
\begin{aligned}
& \langle I\rangle=\langle N\rangle \int_{0}^{\infty} i(t) \mathrm{d} t \\
& \sigma^{2}=\left\langle I^{2}\right\rangle-\langle I\rangle^{2}=\left\langle N>\int_{0}^{\infty} i^{2}(t) \mathrm{d} t\right.
\end{aligned}
$$

ここで $I$ は検出器の出力電流, <I>はその時間平均を表す， $i(t)$ は 1 パルスの電流の時間変化であり, $<N>$ は計数率である。電流の分散 $\sigma^{2}$ は結局計数率とパルス波高の 2 乗に比例するため，フィッション チェンバーのように中性子による波高が $\gamma$ 線によるものより十分大きい場合には， $\gamma$ 線の寄与を除くことが できる.キャンベルモードは $10^{4} \sim 10^{10} \mathrm{cps}$ という広い計数率範囲で使用可能であり, パルス計数モード( $\leqq$ $\left.10^{6} \mathrm{cps}\right)$ と合わせて10桁のダイナミックレンジが得られる。またキャンベルモードとパルス計数モード間で 2 桁のオーバーラップ領域があるので相互較正を行う上からも好都合である.

JT-60U では図 3 に示すよjに, 各フィッションチェンバーのパルス計数回路とキャンベル回路の両方を 設けている。ここでは利得がそれぞれ10倍異なるキャンベル回路を 3 つ並列に使用しており, それぞれ, 出 力電流変化の $\sigma^{2}$ ではなく $\sigma$ を出力するようになっている. 各データをパルス計数モードを含めて計算機に 取り込み，適切なモードまたは測定レンジを自動的に選択し，中性子発生率に変換している，実際に $\gamma$ 線や

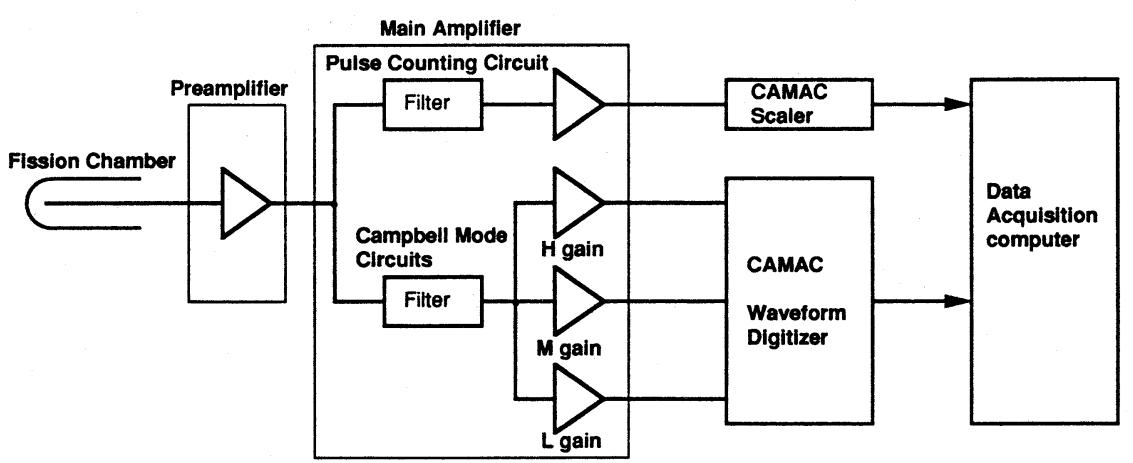

図 3.JT-60Uにおけるフィッションチェンバーを用いた中性子検出器のブロックダイヤグラム. 
硬 X 線の影響がないことは JT-60U の水素放電において, LHCD も含めた種々のプラズマで確認してい

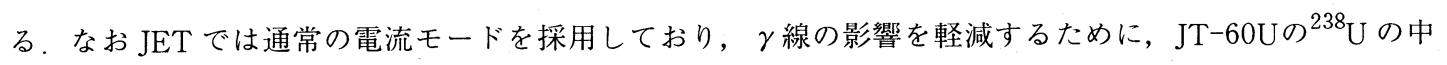
性子検出器と同様な $5 \mathrm{~cm}$ 厚の鉛の $\gamma$ 線遮蔽をポリエチレン減速材の内側に設けている.

\section{3 中性子検出器の配置}

分光測定, 放射損失測定, 中性粒子測定などの通常のプラズマ診断では, スリットやコリメータを使用し て, 測定するプラズマの体積を限定し, そこにおける, 光子または粒子の放出密度からプラズマ全体の総放 出量を評価することが行われているが, 中性子は透過性と散乱性が大きく, これらの方法では, 精度良く 測定対象のプラズマの体積を限定することはできない。そこでトカマクでは, 指向性のない中性子検出器を トカマク近傍に取付けて中性子の発生率を測定することが一般的である。図 4 にJT-60Uにおける中性子 検出器の配置を示す。トカマクの赤道面上, トロイダル磁場コイルの外端の主半径の位置に, ${ }^{235} \mathrm{U}$ および ${ }^{238} \mathrm{U}$ の中性子を一対として 3 ヶ所設置している，その内， 2 ヶ所には，較正のために高感度の ${ }^{3} \mathrm{He}$ 比例計 数管を用いた中性子検出器を設置している。1 1 所の検出器の故障を想定し, 常時 2 ヶ所以上動作するとい う, 信頼性確保の意味から 3 ヶ所設置している。もちろん中性子発生率のトロイダル一様性の確認の意味も 持っているが，今までのところ有意なトロイダル方向の非一様性は見られていない.

JT-60Uでは，大きな計測器が取り付けられていないセクションを選んで中性子検出器を設置しており， できるだけ中性子検出器がプラズマを見込めるように配慮している。 JET では ${ }^{235} \mathrm{U}$ および ${ }^{238} \mathrm{U}$ の中性子 検出器を変流機鉄心の側面に取り付けており, さらに検出器と真空容器の間にトロイダル磁場コイルや結構 大きな計測器が据付けられているのでそれらによる中性子の散乱が大きい ${ }^{15,16)}$. TFTRでも中性子検出器 は真空容器斜め下に取付けられており, コンプレッションパネルの陰になっている ${ }^{17)}$.

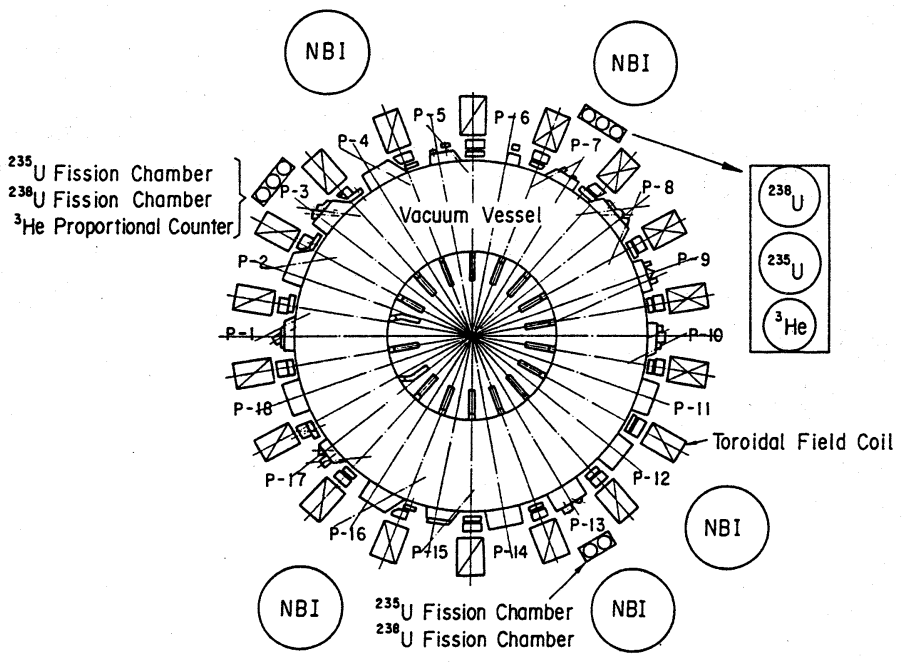

図 4.JT-60U における中性子検出器の配置. 


\section{4. 較正}

中性子発生率測定に扔いて最も重要なことは, 検出器の出力とトーラス全体の中性子発生率との関係を較 正することである。トカマクでは中性子源がトーラス状に広がっており，かつ中性子検出器とこれらの間に は，第一壁，真空容器，コイルなどの構造物が複雑に存在しているので，プラズマの各点で発生した中性子 が検出器に与える寄与は $1 / r^{2}$ だけでは決まらず極めて複雑である。そこで, トカマクの真空容器内に ${ }^{252} \mathrm{Cf}$ などの中性子源を置き, それを移動させて, 真空容器内の各点から検出器の出力に与える寄与(応答関数)を

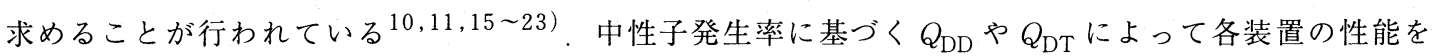
議論するようになると，互いに納得のいく測定方法と較正方法が望まれるようになってきており，1989年 8 月, プリンストンプラズマ物理研究所に, TFTR, JET, JT-60, ASDEX, DIII-D, TORE-SUPRA, FT, TEXTOR，ATF，JIPPT-IIUなど主だったトロイダル装置の中性子計測担当者が集まり，それぞれの装置 の検出法, 較正法の検討を行うワークショップが開かれた。この会議では最終的に, ${ }^{235} \mathrm{U}$ フィッション チェンバーを検出器とし, $\sim 10^{7} \mathrm{n} / \mathrm{s}$ の ${ }^{252} \mathrm{Cf}$ 中性子源を検出器からトロイダル角で士 $90^{\circ}$ の範囲で, プ ラズマ軸上 40 点以上, $\pm 90^{\circ}$ の以外でさらに 20 点以上スキャンすることが, 標準的方法として推奨され $た^{24,25)}$. また較正用の球形ポリエチレ減速材付 ${ }^{3} \mathrm{He}$ 比例計数管をそれぞれの装置に持ち込み同一の検出器 で較正を行うことも提案され，現在ロスアラモス研究所でその検出器の製作が行われている．

$\mathrm{JT}-60 \mathrm{U}$ では重水素実験に先立ち昨年 7 月に, この会議の推奨方法に基づき中性子検出器の較正を行っ た ${ }^{10,26)}$. 図 5 にJT-60Uにおける中性子検出器較正の概要を示す。真空容器内に周回レールを敷設し, ${ }^{252} \mathrm{Cf}$ 中性子源 $\left(400 \mathrm{MBq}\right.$, 中性子発生率 $\left.=4.8 \times 10^{7} \mathrm{n} / \mathrm{s}\right)$ を取り付けたトロッコを遠隔操作で磁気軸上を移

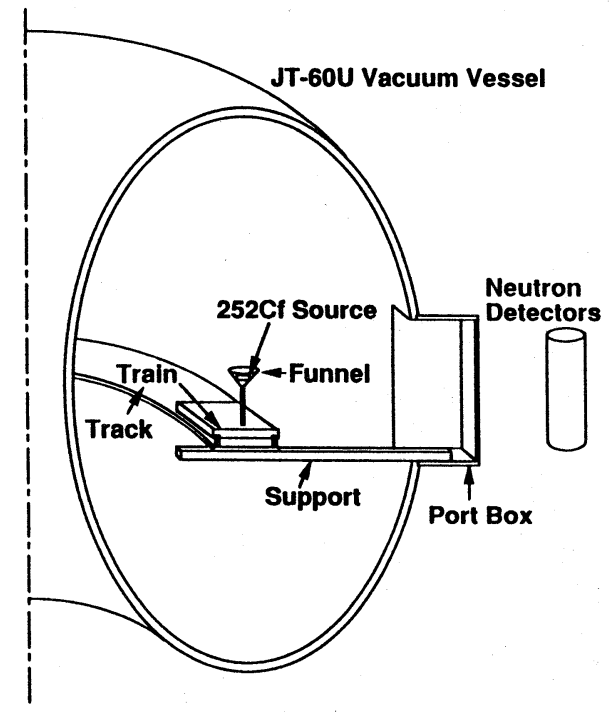

図 5.JT-60U における中性子検出器較正の概要.

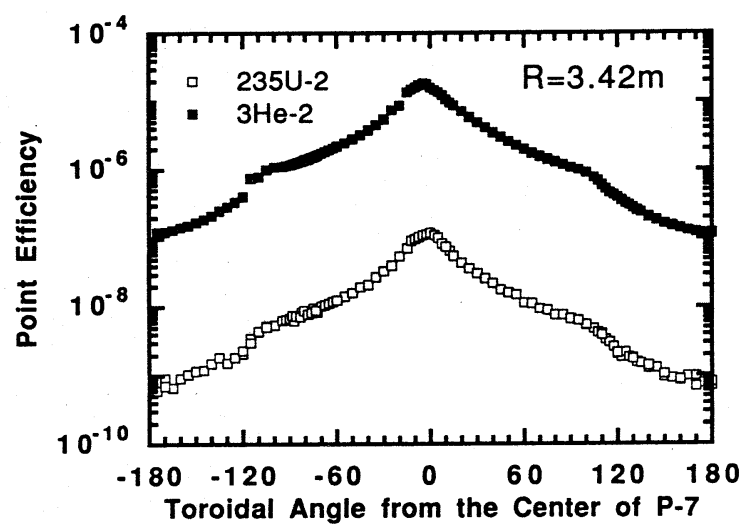

図 6. ${ }^{235} U$ フィッションチェンバー及び ${ }^{3} \mathrm{He}$ 比例 計数管を用いた中性子検出器の ${ }^{252} \mathrm{Cf}$ 点線源 に対する検出効率. 
動させて, 磁気軸上各点から発生する中性子 1 個当たりの計数率を測定した。線源位置はトロイダル角 5 度毎 (検出器前面では 2.5 度毎)に に2 点とし, JT-60U の典型的な 2 つの配位, 標準配位 $(R=3.42 \mathrm{~m}, Z=$ $+0.15 \mathrm{~m})$ と高非円形配位 $(R=3.22 \mathrm{~m}, Z=+0.15 \mathrm{~m})$ の 2 とうりの磁気軸位置で較正を行った.

図 6 に, 磁気軸上各点発生した中性子に対する ${ }^{235} \mathrm{U} と^{3} \mathrm{He}$ の中性子検出器の検出効率(応答関数)を示す. ここで検出器のあるセクション(トロイダル磁場コイルとトロイダル磁場コイルの間)の中心軸を 0 度として いる．線源が中性子検出器の反対側の真空容器の陰に入ると検出効率が急激に減少することがわかる．また ${ }^{3} \mathrm{He}$ の中性子検出器の応答関数は ${ }^{235} \mathrm{U}$ のものとほぼ相似形をしており，約 60 倍になっている。このことは ${ }^{235} \mathrm{U}$ と ${ }^{3} \mathrm{He}$ の中性子検出器の相対感度を調べておけば, もっと強度の弱い中性子源でも較正が可能である ことを示している.

この測定データを 3 次スプラインでフィットした曲線を $\varepsilon(\theta)(\theta$ : トロイダル角)とするとトーラス状線 源 1 個に対する検出効率 $<\varepsilon>$ は,

$$
<\varepsilon>=\frac{\int_{-180^{\circ}}^{+180^{\circ}} \varepsilon(\theta) \mathrm{d} \theta}{\int_{-180^{\circ}}^{+180^{\circ}} \mathrm{d} \theta}
$$

で表される．較正で得られた各検出器の検出効率 $<\varepsilon>$ を表 1 に示す. $R=3.42 \mathrm{~m}$ と $R=3.22 \mathrm{~m}$ で各検出 器とも検出効率が $2 \%$ 異なっていることがわかる.

表 1.トロイダル線状線源に対する中性子検出器の検出効

\begin{tabular}{|c|c|c|c|}
\hline 検出器位置 & 検 & $\langle\varepsilon>(R=3.42 \mathrm{~m})$ & $\langle\varepsilon\rangle(R=3.22 \mathrm{~m})$ \\
\hline $\mathrm{P}-3$ セクション & ${ }^{235} \mathrm{U}$ フィッションチェンバー $\left({ }^{235} \mathrm{U} 1.5 \mathrm{~g}\right)$ & $5.35 \times 10^{-8}$ & $5.26 \times 10^{-8}$ \\
\hline P-3 セクション & ${ }^{3} \mathrm{He}$ 比例計数管 & $3.27 \times 10^{-6}$ & $3.22 \times 10^{-6}$ \\
\hline P-7 セクション & ${ }^{235}$ U フィッションチェンバー $\left({ }^{235} \mathrm{U} 0.3 \mathrm{~g}\right)$ & $1.78 \times 10^{-8}$ & $1.74 \times 10^{-8}$ \\
\hline P-7 セクション & ${ }^{3} \mathrm{He}$ 比例計数管 & $2.83 \times 10^{-6}$ & $2.79 \times 10^{-6}$ \\
\hline P-13セクション & ${ }^{235} \mathrm{U}$ フィッションチェンバー $\left({ }^{235} \mathrm{U}\right.$ 0.3g) & $1.92 \times 10^{-8}$ & $1.88 \times 10^{-8}$ \\
\hline
\end{tabular}

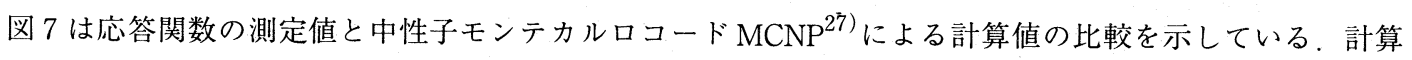
では建屋壁を含めたJT-60Uを 3 次元でモデル化している，検出器自体の感度が正確には解っていないので (据付け後, ディスクリレベル等を最終的に設定していることによる), 0 度の位置で計算值と測定值を規格 化している．トロ.イダル角の絶対值が大きくなるにつれて計算值の方が大きくなっており，中性子の散乱・ 吸収が過小評価になっていることが伺える。計算值から求めたトーラス状線源に対する検出効率は測定值よ り24\%大きくなっている，この原因としてはモデル化の精度, 検出器の感度曲線(図 2 参照)の誤差などが考 えられるが，さらに精度の高いモデル化を行ったTFTRでも計算值の方が $20 \%$ 大きく，モデル化した全ての 物質の原子数密度を $20 \%$ 増加させると点線源に対する検出効率が全ての点で測定値と良く一致することを示 しており，MCNPで使用している断面積に問題がある可能性もある。 


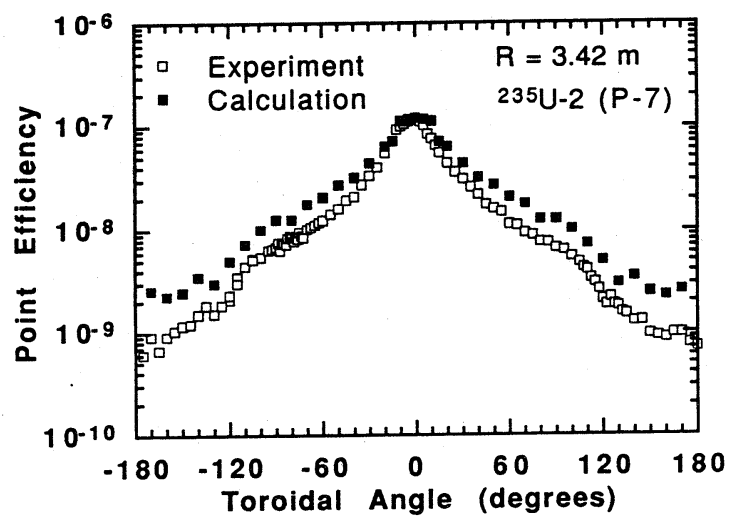

図 7. ${ }^{235}$ U フィッションチェンバー中性子検出器の ${ }^{252} \mathrm{Cf}$ 点線源に対する検出効率の測定值とモン テカルロ計算 (MCNP) との比較.

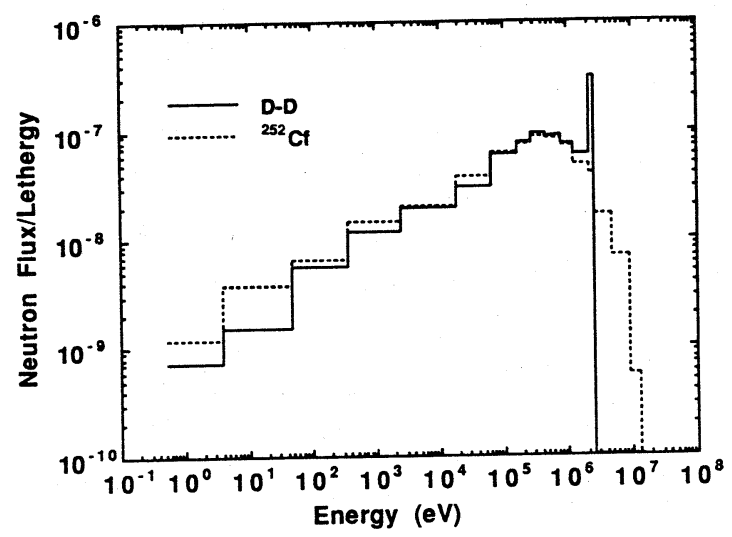

図 8. ${ }^{252} \mathrm{Cf}$ 及び DD 中性子源に対する中性子 検出器位置における中性子エネルギース ペクトル(MCNPによる).
表 2.JT-60U における中性子発生率の測定誤差

\begin{tabular}{|l|l|}
\hline${ }^{252} \mathrm{Cf}$ 中性子源強度 & $\pm 1.5 \%$ \\
\hline 較正の統計誤差 & $\pm 0.3 \%$ \\
\hline トロッコ, レールによる散乱 & $\pm 5 \% *$ \\
\hline Cf $\mathrm{DD}$ のエネルギーによる誤差 & $\pm 5 \% *$ \\
\hline 中性子発生分布 & $\pm 5.5 \% *$ \\
\hline プラズマ位置変化 & $\pm 2 \%$ \\
\hline キャンベル/パルス計数の相対較正 & $\pm 5 \%$ \\
\hline キャンベルモード直線性 & $\pm 1 \%$ \\
\hline 合計 (2乗平均) & $\pm 11 \%$ \\
\hline (*モンテカルロ計算による)
\end{tabular}

実際の DD プラズマの中性子エネル ギーは2. $45 \mathrm{MeV}$ であるのに対し，較正 に使用した ${ }^{252} \mathrm{Cf}$ は平均エネルギー2.1 $\mathrm{MeV}$ のマックスウェル分布である。この 中性子源のエネルギーの違いによる影響 は，MCNPによる計算で評価している， MCNPによる計算は上記のように絶対 值では20\%程度の誤差はあるが，相対的 な評価では信頼性があると考えている， $\mathrm{DD}$ 中性子源と ${ }^{252} \mathrm{Cf}$ 中性子源に対する， 中性子検出器位置における中性子エネル ギースペクトルの計算結果を図 8 に示 す。 $1 \mathrm{MeV}$ 以下では，両者は良く一致し ていることがわかる。このスペクトルか ら計算した検出効率の比は, $\langle\varepsilon\rangle_{\mathrm{DD}} /$ $<\varepsilon>_{\mathrm{Cf}}=0.99 \pm 5 \%$ ありり, 両者の検出効率は良く一致した。しかし, この比は, 検出器の感度曲線, 卜 カマク装置の構造, 検出器の取付り位置にある程度依存するので, この結果が一般性を持つ訳ではない.ち なみにTFTRの計算では, $\left\langle\varepsilon>_{\mathrm{DD}} /<\varepsilon>_{\mathrm{Cf}}=1.08 \pm 7 \%\right.$ が得られている.

同様に, MCNP を使用して, レールなどの較正用機器による散乱の効果, 実際のプラズマでは中性子発生 源がポロイダル面内で分布を持つことによる効果を評価した。また較正に使用したパルス計数モードとキャ ンベルモード間の相対較正は重水素の $\mathrm{OH}$ 放電を利用して行った。 さらにキャンベルモードの直線は原子炉 を使用し，その出力を 6 桁に渡って，変化させることによって確認した，それらによる，中性子発生率の測

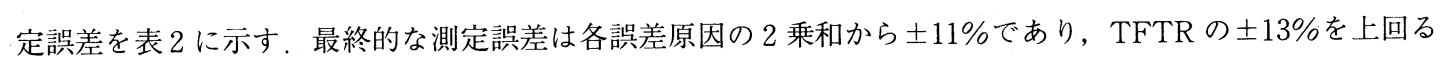
精度を得ている。 


\section{JT-60Uにおける測定例と核融合利得 $Q$ の評価}

JT-60U では昨年(1991年) 7 月より重水素実験を開始したが，昨年 9 月に高イオン温度モードの放電によ り最大中性子発生率 $1.3 \times 10^{16} \mathrm{n} / \mathrm{s}$ を得た。その放電の波形を図 9 に示す。 $\mathrm{OH}$ フェーズで $10^{10} \mathrm{n} / \mathrm{s}$ 以下の中 性子発生率であったものが, 約 $20 \mathrm{MW}$ の NBI 加熱を行うと約 $100 \mathrm{~ms}$ で $10^{15} \mathrm{n} / \mathrm{s}$ まで達成し, その後も中性子 発生率は上昇するが, $\mathrm{NBI}$ 加熱 $900 \mathrm{~ms}$ で $\beta_{\mathrm{p}}$ コラップスが発生し, 中性子発生率が急落している. 最大中性

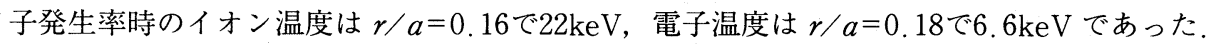

核融合利得 $Q$ の評価は中性子発生率測定の大 きな目的の 1 つである。重水素プラズマでは, 良く知られているように次ぎの 2 つの核融合反 応が主に起こる。

$$
\begin{aligned}
& \text { (1) } \mathrm{D}+\mathrm{D} \rightarrow{ }^{3} \mathrm{He}(0.82 \mathrm{MeV})+\mathrm{n}(2.45 \mathrm{MeV}) \\
& (2 \mathrm{D}+\mathrm{D} \rightarrow \mathrm{T} \quad(1.01 \mathrm{MeV})+\mathrm{p}(3.03 \mathrm{MeV})
\end{aligned}
$$

(1)と(2)の反応はほほ同じ確率で起こるため, 中性子発生率を $S_{\mathrm{n}}$, 全核融合反応率 (Fusion Reactivity)を $R_{\mathrm{DD}}$ とすると, $R_{\mathrm{DD}} \sim 2 S_{\mathrm{n}}$ であ る. また核融合出力は $P_{\mathrm{FUSION}(\mathrm{DD})}=E_{\mathrm{DD}} \cdot R_{\mathrm{DD}}$ $\left(E_{\mathrm{DD}}=3.27+4.04 \mathrm{MeV}\right)$ となる. しかし(2)の反 応では生成粒子が全て荷電粒子であるため, 複 合核のクーロン障壁により, 反応断面積が(1)よ

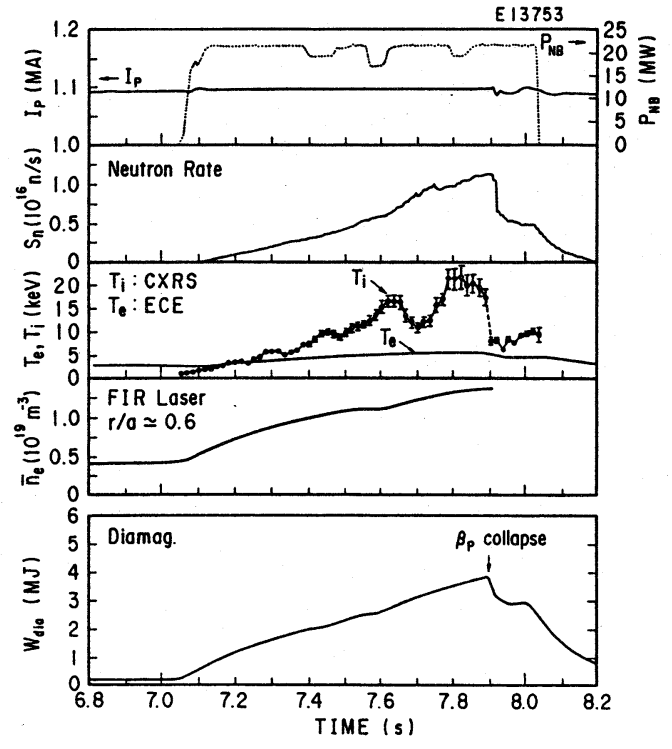

図 9.JT-60U において最大中性子発生率 $\left(1.3 \times 10^{16} \mathrm{n} / \mathrm{s}\right)$ を得た放電の波形. り数\%〜10\%小さい. また(1)と(2)の断面積の比は入射重水素のエネルギーに依存するため, 正確には, 解析 コードを使用して中性子発生率を熱核融合反応，ビーム成分一熱成分反応，ビーム成分ービーム成分反応の 3 成分に分け，各成分毎に(2)の反応率を計算して核融合出力を評価しなければならない.

核融合利得 $Q$ はプラズマへの入力と核融合出力の比 $\left(P_{\mathrm{FUSION}} / P_{\mathrm{INPUT}}\right)$ として定義されるが, 具体的な計 算方法は装置によって異なっている，核融合利得 $Q$, 特にDT 換算の $Q_{\mathrm{DT}}$ は物理 $/$ 工学な意味ばかりでな く，各装置にとって予算獲得，宣伝など戦略的意味合いも大きい，まずJETでは次ぎの式を用いている ${ }^{28)}$.

$$
Q=\frac{P_{\mathrm{TT}}}{P_{\mathrm{abs}}-\dot{W}}+\frac{P_{\mathrm{BT}}+P_{\mathrm{BB}}}{P_{\mathrm{abs}}} \quad, \quad P_{\mathrm{abs}}=P_{\mathrm{OH}}+P_{\mathrm{NB}}-P_{\text {Shinethrough }}
$$

ここで $P_{\mathrm{TT}}, P_{\mathrm{BT}}, P_{\mathrm{BT}}$ は核融合出力の内, 熱核融合反応，ビーム成分一熱成分反応，及びビーム成分一ビー ム成分反応の各成分を表している。また $\dot{W} は$ 蓄積エネルギーの時間微分, $P_{\text {Shinethrough }}$ はBI の突き 
抜けパワーである。JETでは多くの放電において中性子発生率や蓄積エネルギーの増加がカーボンブルーム

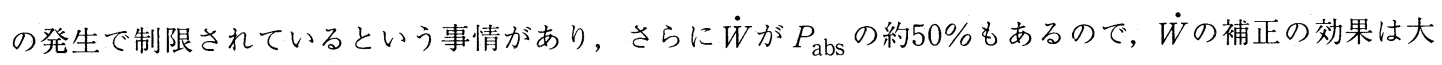
きい。これに対しTFTRは $\dot{W} や P_{\text {Shinethrough }}$ の補正を行うべきでないと主張しており，

$$
Q=\frac{P_{\mathrm{FUSTON}}}{P_{\mathrm{IN}}}, P_{\mathrm{IN}}=P_{\mathrm{OH}}+P_{\mathrm{NB}}
$$

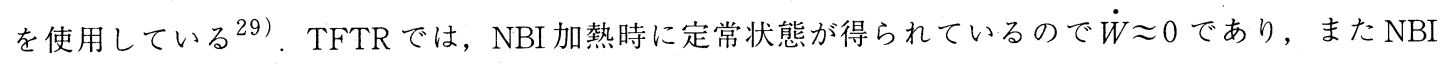
は接線入射なので $P_{\text {Shinethrough }} \approx 0$ という事情もある.JT-60Uでは, NBI の突き抜けは回収可能のパ ワーであるが, $\dot{W}$ を補正する理由がないとの考えから, 図 9 の放電は $\dot{W} \sim 0.3 P_{\mathrm{abs}}$ ではあるが, 次のように $P_{\text {Shinethrough }}$ のみ補正している.

$$
Q=\frac{P_{\mathrm{FUSION}}}{P_{\mathrm{abs}}} \quad, P_{\mathrm{abs}}=P_{\mathrm{OH}}+P_{\mathrm{NB}}-P_{\text {Shinethrough }}
$$

$Q_{\mathrm{DD}}$ の評価では, $P_{\mathrm{FUSION}}$ は中性子発生率から容易に求まるが, 重水素プラズマから DT プラズマに換算 した $Q_{\mathrm{DT}}$ では, 解析コードを使用し, 実測された温度, 密度, $Z_{\mathrm{eff}}$ 等を固定し, プラズマの種類のみを DT に代えて，その時の核融合出力を計算する必要がある. NBI 加熱プラズマの場合, プラズマ及びビーム の種類として，(1) $D^{\circ} \rightarrow T$, (2) $T^{\circ} \rightarrow D$, (3) $D^{\circ} \rightarrow D+T$, (4) $T^{\circ} \rightarrow D+T$, (5) $D^{\circ}+T^{\circ} \rightarrow D+T$ の 5 通りが考えられ る.JET，TFTRでは，それぞれ計画しているDT 実験を想定して，(1)及び(5)を採用している．JT-60Uでは DT 実験の計画を有していないので，ITER 等で想定している(3)よって $Q_{\mathrm{DT}}$ を評価している，ちなみに図 9 に示した JT-60U の放電は， $P_{\text {Shinethrough }}$ を補正すると $P_{\text {abs }} \sim 17 \mathrm{MW}$ であり， $Q_{\mathrm{DD}}=0.9 \times 10^{-3}$ となる. 熱核融合反応，ビーム成分一熱成分反応，及びビーム成分一ビーム成分反応の各成分はそれぞれ $27 \% ， 53 \%$ ， $20 \%$ になっている. (3)の条件で核融合出力を計算すると， $P_{\mathrm{FUSION}}=3.4 \mathrm{MW} て ゙ あ り ， Q_{\mathrm{DT}}=0.2$ を得ている.

\section{5. おわりに}

以上, JT-60U を中心にトカマクで行われている中性子発生率測定の現状と, その絶対較正について述べ てきた、いずれの大型トカマク装置でもフィッションチェンバーを使用した中性子検出器によって中性子発 生率を測定しており，その較正方法として ${ }^{252} \mathrm{C}$. 中性子源を真空容器内でスキャンする方法が共通に行われ ている。 さらに共通の較正用中性子検出器を ALCATOR C-MOD, TFTR ど持ち込んで較正を行うことも 計画されて扔り，重水素プラズマに対する中性子発生率の測定と較正に関してはかなり標準化が進んでい る、TFTR および JETではそれぞれ1993年，1994年に本格的な DT 実験を計画しているが, ${ }^{252} \mathrm{Cf}$ と DT 中性子 $(14 \mathrm{MeV})$ ではエネルギーが大きく異なるので，この較正方法では精度が悪くなる。 JET では ${ }^{252} \mathrm{Cf} に$ よる較正をあきらめ，放射化箔法で較正することにしているが，放射化法でも測定点の中性子フルエンスと 全発生量の関係を較正する必要性は残る。この較正はMCNPによるモンテカルロ計算で行っているが, 放射化䈃法の測定点はプラズマに近く，その分計算の精度も上がるという利点はあるものの，計算だけでは 
やはり不安がある.TFTR では $14 \mathrm{MeV}$ の中性子発生装置(小型の加速器)を真空容器内に持ち込んで較正を 行っているが，中性子源の非等方性や中性子発生装置自体による散乱・呼吸のために精度がでないと報告し ている ${ }^{19)}$ ，近づく本格的な DT 実験に向けて，新たな較正法の確立が必要である．

一方, 中性子発生率測定の大きな目的の 1 つである核融合利得 $\mathrm{Q}$ の評価では, 各者各様の定義式を使用 している．特に $Q_{\mathrm{DT}}$ は，その值のみが一人歩きしやすいので早急にその統一が計られることを望んでいる。

\section{謝 辞}

JT-60U の中性子検出器較正に参加・協力頂いた, 竹内 浩, 長島 章, 近藤 貴, 逆井 章, 伊丹 潔, 飛田健次, 永島圭介, 閏谷 譲, 小出芳彦, 河野康則, 井手俊介, 根本正博, 栗山正明, 伊藤孝雄, 宇佐美 広次，国枝俊介，井口哲夫，金子純一，中山田憲昭，田中信彰，笹尾真実子，杉山 隆，畑山明聖，北 好 夫, 関 英治, Cris W. Barnesの各氏に深く感謝いたします。また有意義な議論を頂いた, J.D. Strachan, D.L. Jassby, O.N. Javis の各氏に謝意を表します．

\section{参考文献}

1) H. Brysk : Plasma Phys. 15 (1973) 611.

2) M. C. Zarnstorff et al. : Plasma Phys. and Controll. Nucl. Fusion Research 1988 (Proc. 12th Conf., Nice) IAEA, Vienna (1989) Vol. 1, p. 183.

3) J. M. Adams, B. Balet, D. A. Boyd, D. J. Campbell et al. : Nucl. Fusion 31 (1991) 891

4) B. H. Duan : BNWL-1685, (1972).

5) L. M. Hively : Nucl. Fusion 17 (1977) 873

6) J.D. Strachan, P. L. Colestock, S. L. Davis et al. : Nucl. Fusion, 21 (1981) 67.

7) S. Niikura, M. Nagami and H. Horiike : Fusion Eng. Design 6 (1988) 181.

8) M. Pillon et al. : Fusion Technology 15 (1989) 1420.

9) E. B. Nieschmit : Rev. Sci. Instrum. 57 (1986) 1757.

10) T. Nishitani et al. : JAERI-M 91-176, (1989).

11) O.N. Javis et al. : JET Joint Undertaking Rep. JET-IR (84) 02, (1984).

12) A. C. England, H.W. Hendel et al. : Rev. Sci. Instrum. 57 (1986) 1754.

13) H. W. Hendel, A. C. England et al. : J. Fusion Energy 5 (1986) 231.

14) D. L. Jassby, H.W. Hendel, H.-S. Bosch : Rev. Sci. Instrum. 59 (1988) 1688.

15) O.N. Javis et al. : JET Joint Undertaking Rep. JET-IR (85) 06; (1984).

16) O.N. Javis et al. : Rev. Sci. Instrum. 61 (1990) 3172.

17) Cris W. Barnes, M. Bell, H.W. Hendel et al. : Rev. Sci. Instrum. 61 (1990) 3151.

18) H.W. Hendel, D. L. Jassby, H. S. Bosh et al. : Rev. Sci. Instrum. 59 (1988) 1682.

19) H.W. Hendel, R. W. Palladio, Cris W. Barnes et al. : Rev. Sci. Instrum. 61 (1990) 1900.

20) G. Zankel, J.D. Strachan, R. Lewis et al. : Nucl. Instrum. Methods 185 (1981) 321.

21) K. Hubner et al. : 16th Europ. Conf. on Controll. Fusion and Physics, (Venice, 1989) part 4, p. 1453.

22) M. Angelone, P. Batistoni, L. Bertalot et al. : Rev. Sci. Instrum. 61 (1990) 3157.

23) C.L. Fiore and R. S. Grenetz : Rev. Sci. Instrum. 61 (1990) 3166

24）笹尾真実子, 西谷健夫：核融合研究 62 (1989) 415 .

25) J. D. Strachan, J. M. Adams et al. : Rev. Sci. Instrum. 61 (1990) 3501.

26) T. Nishitani et al. : to be published in Rev. Sci. Instrum.

27) Los Alamos Monte Carlo Group, LANL, Report LA-7396-M, Rev. 2 (1986).

28) B. Belet et al. : 17th Europ. Conf. on Controll. Fusion and Physics, (Amsterdam, 1990) part 1, p. 106.

29) D. M. Meade et al. : Plasma Phys. and Controll. Nucl. Fusion Research 1990 (Proc. 13th Conf. Washington DC) IAEA, Vienna (1991) Vol. 1, p.9. 